\title{
Analisis Penerapan Job Order Costing Method Terhadap Harga Pokok Produksi Untuk Meningkatkan Akurasi Harga Jual Produk Pada Maju Jaya Aluminium Kecamatan Cina Kabupaten Bone
}

\author{
Martinah \\ Institut Agama Islam Negeri (IAIN) BONE \\ martinah@gmail.com
}

\author{
Muctar Nuhung \\ Sekolah Tinggi Agama Islam (STAI) Al -Furqan Makassar \\ mnuhung@gmail.com
}

\begin{abstract}
This study aims to compare the cost of the 2M CA type of storefront production that has been applied in Forward Jaya Aluminum by calculating the production cost principle using the job order costing method. Data is collected through observation, interviews, and documentation. Furthermore, the data is analyzed using qualitative methods. While the calculation method used in this study is the method of job order costing or the cost of the order. The results of the study found that the calculation of the cost of production of type 2 M CA storefront was IDR 1,300,000 with a set profit rate of $19.6 \%$ with a selling price of IDR 1,550,000, while the calculation using the job order costing method was equal to Rp 1,329,217 with a selling price of Rp 1,589,744 with a profit rate of $19.6 \%$. Based on the results of his analysis, the difference in the calculation of cost of goods manufactured is due to the fact that Maju Jaya Aluminum does not identify in detail the elements of the cost of production, so the cost of production calculated by Maju Jaya Aluminum is lower than using the job order costing method. We recommend that Maju Jaya Aluminum correct the calculation of cost of goods manufactured according to the job order costing method by calculating and identifying raw material costs, direct labor costs, and factory head costs so that the specified selling price can be accurate and increase.
\end{abstract}

Keywords: Costing Method Job Order, production, and product selling price 


\begin{abstract}
Abstrak
Penelitian ini bertujuan untuk mengetahui perbandingan harga pokok produksi etalase jenis $2 \mathrm{M}$ CA yang selama ini diterapkan Maju Jaya Aluminium dengan perhitungan karga pokok produksi dengan metode job order costing. Data dikumpulkan melalui observasi, wawancara, dan dokumentasi. Selanjutnya, data tersebut dianalisis dengan menggunakan metode kualitatif. Sedangkan metode perhitungan yang digunakan dalam penelitian ini adalah metode job order costing atau harga pokok pesanan. Hasil penelitian yang didapatkan menemukan bahwa perhitungan harga pokok produksi etalase jenis 2 M CA adakah sebesar Rp 1.300.000 dengan tingkat keuntungan yang ditetapkan senilai 19,6\% dengan harga jual sebesar Rp 1.550.000, sedangkan perhitungan dengan menggunakan metode job order costing adalah sebesar $R p$ 1.329.217 dengan harga jual sebesar Rp 1.589.744 dengan tingkat keuntungan 19,6\%. Berdasarkan hasil analisisnya didapatkan perbedaan perbedaan perhitungan harga pokok produksi disebabkan karena Maju Jaya Aluminium tidak mengidentifikasi secara rinci unsur unsur harga pokok produksi, sehingga harga pokok produksi yang dihitung oleh Maju Jaya Aluminium lebih rendah dibanding dengan menggunakan metode job order costing. Sebaiknya Maju Jaya Aluminium melakukan koreksi perhitungan harga pokok produksi sesuai dengan metode job order costing dengan menghitung dan mengidentifikasi biaya bahan baku, biaya tenaga kerja langsung, dan biaya ovrhead pabrik agar harga jual yang ditetapkan bisa akurat dan mengalami peningkatan.
\end{abstract}

Kata Kunci : Job Order Costing Method, produksi, dan harga jual produk

\title{
PENDAHULUAN
}

Maju Jaya Aluminium pertama kali beroperasi pada bulan Agustus 2016, sehingga usaha ini masih terbilang sebagai usaha yang kecil dan sedang berkembang. Menurut Hj. Salmiati selaku tetangga dari tempat usaha ini, mengatakan bahwa "Meskipun masih terbilang usaha yang baru, tetapi sejak pertama kali didirikan , Maju Jaya Aluminium ini beroperasi secara berkesinambungan meski termasuk jenis usaha yang berproduksi berdasarkan pesanan dari konsumen". ${ }^{1}$ Berdasarkan data penjualan produk usaha ini selama satu tahun terakhir dimulai dari pertama beroperasi sudah manerima sebanyak 150 pesanan pembuatan produk dari konsumen. Menyangkut laba atau keuntungan yang didapatkan Maju Jaya Aluminium ini berkisar

\footnotetext{
${ }^{1}$ Hj. Salmiati, Tetangga Tempat Usaha Maju Jaya Aluminium, Kelurahan Tanete Kabupaten Bone, Sulawesi Selatan, Wawancara oleh penulis di Kelurahan Tanete, 03 Oktober 2017. 
dengan laba kotor bisa mencapai sebanyak Rp 7.000.000; - Rp 10.000.000; laba kotor sedangkan laba bersih yang pernah dicapai sebanyak Rp 3.000.000; - Rp 5.000.000; per bulannya.

Maju Jaya Aluminium termasuk usaha mikro kecil menengah (UMKM) yang berkembang di lingkungan pemukiman warga.Dari beberapa sektor yang ada di Kota Watampone salah satunya yaitu sektor industri yang bergerak dibidang perhotelan, properti, makanan, minuman dan sebagainya memiliki kontribusi yang cukup besar bagi pendapatan daerah. ${ }^{2}$ Kontribusi tersebut dapat dilihat pada tabel 1.1 berikut tentang laju pertumbuhan produk domestik regional bruto atas dasar harga konstan 2010 Menurut Lapangan Usaha di Kabupaten Bone dari Tahun 2013-2016 (Persen):

Tabel 1.1

Pertumbuhan Produk Domestik Regional Bruto Atas Dasar Harga Konstan 2010 Menurut Lapangan Usaha Di Kabupaten Bone

\begin{tabular}{|c|c|}
\hline Tahun & Persen \% \\
\hline 2013 & 6,30 \\
2014 & 9,53 \\
2015 & 8,29 \\
2016 & 9,06 \\
\hline
\end{tabular}

Sumber : Badan Pusat Statistik (BPS) Kab. Bone

Dari data perkembangan domestik regional bruto atas dasar harga konstan 2010 menurut lapangan usaha di Kabupaten Bone dari Tahun 2013-2016 yang mengalami kenaikan setiap tahunnya dan penyokong perkembangan itu adalah salah satu nya sektor makanan dan minuman. Dari pertumbuhan itu, tentu akan berdampak baik dan menjanjikan bagi usaha yang memproduksi produk kebutuhan dari usaha makanan dan minuman tersebutdalam hal ini Maju Jaya Aluminium seperti halnya etalase. Berdasarkan hasil wawancara dengan pemilik Maju Jaya Aluminium bahwa produk yang banyak dipesan konsumen adalah etalase khususnya etalase jenis $2 \mathrm{M} \mathrm{CA}$.

\footnotetext{
2 Badan Pusat Statistik, Kabupaten Bone Dalam Angka2017 (Watampone: BPS, 2017), h. 297.
} 
konsumen berasal dari pengusaha dalam bidang penjualan makanan, minuman, ataupun untuk penjualan produk- produk yang terkait dengan produk tersebut.

Sebuah usaha didirikan tentu memiliki tujuan yang ingin dicapai. Dari sekian banyak tujuan tersebut, yang paling utama adalah mendapatkan keuntungan atau laba. Karena itu untuk mencapai laba yang diinginkan oleh perusahaan salah satu cara yang dilakukan agar dapat menarik minat konsumen adalah menentukan harga yang tepat untuk produk yang terjual. Harga yang tepat adalah harga yang sesuai dengan kualitas produk dan dapat memberikan kepuasan kepada konsumen. Sehingga, laba yang diperoleh perusahaan sesuai dengan yang diharapkan. ${ }^{3}$ Untuk meningkatkan akurasi atau ketepatan harga jual produk tentu berpacu dari pada penentuan harga pokok produksi. Harga pokok produksi merupakan faktor yang penting dalam pertimbangan untuk menetapkan harga jual yang sesuai dengan biaya produksi yang telah dikeluarkan untuk memproduksi pesanan dan nantinya diharapkan untuk memperoleh laba. ${ }^{4}$

Metode perhitungan biaya berdasarkan pesanan adalah job order costing method. Metode job order costing adalah suatu metode pengumpulan biaya produksi untuk menentukan harga pokok produksi pada perusahaan atas dasar pesanan. ${ }^{5}$ Perhitungan biaya berdasarkan pesanan mengakumulasikan biaya bahan baku langsung, tenaga kerja langsung, dan biaya overhead pabrikyang dibebankan ke setiap pesanan. ${ }^{6}$

Berdasarkan pengamatan yang dilakukan penulis terhadap perhitungan harga pokok produksi pada Maju Jaya Aluminuim tidak terlalu memperhatikan biaya tidak langsung atau overhead pabrik yakni sewa gedung, biaya listrik, telepon, penyusutan hingga perawatan mesin dan peralatan. Semua biaya tersebut terlibat selama proses

\footnotetext{
${ }^{3}$ Nurul Islaili, "Harga Pokok Produksi Untuk Menentukan Harga Jual PadaUKM Caula Di Sidoarjo" Sekolah Tinggi Ilmu Ekonomi Indonesia (STIESIA) Surabaya, Vol. 2, NO. 8, 2013, h. 4

${ }^{4}$ Nurul Islaili, "Harga Pokok Produksi Untuk Menentukan Harga Jual PadaUKM Caula Di Sidoarjo" Sekolah Tinggi Ilmu Ekonomi Indonesia (STIESIA..., h. 4

${ }^{5}$ Enita, Metode Harga Pokok Pesanan (Job Order Costing Method)" dalam https://www.kompasiana.com, 9 November 2015

${ }^{6}$ Warren, Call S,Prinsip- Prinsip Akuntansi, ( Cet. I; Jakarta:Erlangga, 2000), h. 144. 
produksi dan juga tempat usahanya bukan milik sendiri tetapi di sewa setiap tahunnya, maka dalam perhitungan harga pokok produksinya pun harus diperhitungkan secara keseluruhannya. Karena, jika perhitungannya tidak akurat, maka harga pokok produksi pun tidak akan akurat dan akan berdampak bagi harga jual produk nantinya. Berdasarkan teori akuntansi biaya, perusahaan yang beroperasi secara pesanan mengakumulasikan biaya overhead pabrik dalam penentuan harga pokok produksi agar harga jual yang diberikan nantinya akan memberikan feed back positif bagi pembeli dan usaha yang bersangkutan. Perhitungan biaya tidak langsung atau overheadpabrik akan dengan menggunakan metode harga pokok pesanan (Job order costing method). Berdasarkan pada latar belakang masalah diatas maka penulis merumuskan permasalahan sebagai pembahasan pokok yang akan dibahas pada pembahasan selanjutnya. Rumusan masalah tersebut sebagai berikut, Bagaimana perhitungan harga pokok produksi yang selama ini diterapkan Maju Jaya Aluminum, Bagaimana perhitungan harga pokok produksi dengan metode Job Order Costing pada Maju Jaya Aluminium dan Bagaimana perbandingan perhitungan harga pokok produksi yang selama ini dilakukan oleh Maju Jaya Aluminium dengan metode perhitungan harga pokok produksi menggunakan Job Order Costing.

\section{METODE}

\section{Jenis Penelitian}

Jenis penelitian yang dilakukan dalam penelitian ini menggunakan penelitian lapangan ( field research ). Penelitian lapangan ( field research)adalah penelitian yang dilakukan di lapangan atau pada responden. ${ }^{7}$ Merupakan penelitian lapangan karena penelitian ini dilakukan dengan langsung mendatangi objek usaha yang terkait yaitu Maju Jaya Aluminium dengan melakukan pengamatan dan wawancara kepada pemilik usaha.

\section{Pendekatan Penelitian}

${ }^{7}$ Iqbal Hasan, Analisis Data Penelitian dengan Statistik , ( Cet.4; Jakarta:Bumi Aksara, 2009), h. 5 
a. Pendekatan Kualitatif

Pendekatan kualitatif merupakan pendekatan yang memusatkan perhatian pada prinsip- prinsip umum yang mendasari perwujudan sebuah makna dari gejala- gejala sosial masyarakat untuk mendapatkan gambaran umum mengenai kategorisasi tertentu.. ${ }^{8}$ Pendekatan kualitatif sendiri merupakan metode penelitian lapangan. Pendekatan kualitatif berupaya memahami perilaku dan lembaga dengan memahami sebaik-baiknya oarang-orang yang terlibat. ${ }^{9}$ Berangkat dari penjelasan tersebut, peneliti akan mendapatkan gambaran dan memahami perilaku pemilik usaha Maju Jaya dalam Mengakumulasikan biaya- biaya yang terkait dengan produksinya sehingga bisa menetapkan harga pokok produksi dari produk terkait tentunya dengan berlandaskan prinsip ekonomi Islam.

b. Pendekatan Ekonomi Islam

Dalam pendekatan ekonomi Islam peneliti memfokuskan pada harga, harga dalam ekonomi lebih kepada penetapan harga yang adil yang berlandaskan al-Qur'an demi tercapainya mașlāḥah, Penelitian ini menjadikan maș/āḥah sebagai pendekatan dan didialogkan dengan penerapan Job Order Costing Method dalam menghitung harga pokok produksi dengan mengakumulasikan semua biaya yang terkait dengan proses produksi produk dan akan didialogkan pada bagaian pembahasan di .

c. Pendekatan Sosiologis

Pendekatan sosiologis adalah ilmu yang mempelajari hidup bersama dalam masyarakat, dan ikatan-ikatan antara manusia yang menguasai hidupnya itu. ${ }^{10}$ Oleh karena itu pendekatan sosiologis perlu karena dalam penelitian ini penulis akan banyak berinteraksi langsung dengan pemilik usaha dan para pekerja Maju Jaya Aluminium agar data dan informasi yang dibutuhkan selama proses penelitian ini menjadi akurat dan nyata adanya.

\footnotetext{
${ }^{8}$ Burhan Bungin, Sosiologi Komunikasi : Teori, Paradigma, dan Diskursus Teknologi Komunikasi di Masyarakat Ed. 1, ( Cet. VI; Jakarta: Kencana Prenada Group, 2013), h. 306.

${ }^{9}$ Baharuddin Ilyas, Muhammad Arif Tiro, Metodologi Penelitian untuk Ilmu-Ilmu sosial dan Ekonomi (Cet. I;, Makassar: Andira Publisher, 2002), h. 241.

${ }^{10}$ Abuddin Nata, Metodologi Study Islam, Ed.I (Cet. VII; Jakarta: PT. Raja Grafindo Persada, 2003), h. 38.

Jurnal Ilmiah Al Tsarwah 


\section{Lokasi Penelitian}

Lokasi penelitian dilaksanakan di Maju Jaya Aluminium yang beralamat di Jl. Poros Sinjai, Kecamatan Cina, Kabupaten Bone, Provinsi Sulawesi Selatan.

\section{Data dan Sumber Data}

Sumber perolehan data yang digunakan dalam penelitian ini adalah data Primer. Data primer merupakan jenis data yang diperoleh dari sumber utama (Sumber asli), baik berupa data kualitatif maupun kuantitatif. Sesuai dengan asalnya dari mana data tersebut diperoleh, maka data ini sering pula disebut dengan istilah data mentah ( Raw data). ${ }^{11}$ Data primer merupakan sumber data yang didapat langsung dari sumber pertama yaitu individu atau perseorangan. ${ }^{12}$

Dalam hal ini,data primer yang dugunakan dalam penelitian ini adalah data kualitatif dan data kuantitatif . Data kualitatif berupa hasil wawancara langsung dengan pemilik usaha Maju Jaya Aluminium . Sedangkan data kuantitatif yang digunakan berupa data biaya dalam proses produksi, harga, dan kuantitas yang diproduksi serta data tentang daftar penjualan produk

\section{Instrumen Penelitian}

Instrumen penelitian adalah suatu alat yang digunakan mengukur fenomena alam maupun sosial yang diamati. Secara spesifik semua fenomena ini disebut sebagai variabel penelitian. ${ }^{13}$ dalam literatul lain disebutkan bahwa instrumen penelitian adalah alat yang digunakan oleh peneliti dalam mengumpulkan data agar pekerjaannya lebih mudah dan hasilnya lebih baik. Dalam penelitian ini peneliti memperoleh data menggunakan metode wawancara dan observasi maka

\footnotetext{
${ }^{11}$ Muhammad Teguh, Metodologi Penelitian Ekonomi: Teori dan Aplikasi, Ed. 1 ( Cet. III; Jakarta:Raja Grafindo Persada, 2005), h. 122.

${ }^{12}$ Sukandarrumidi, Metodologi Penelitian, (Cet. 4; Yogyakarta: Gajah Mada University Press, 2012), h. 45

${ }^{13}$ Sugiyono, Metode Penelitian Bisnis, ( Cet. X; Bandung: CV. Alfabeta, 2007), h. 97. 
instrumen penelitian yang digunakan adalah pedoman wawancara, alat perekam, kamera dll. ${ }^{14}$

\section{Teknik Pengumpulan Data}

Metode yang digunakan dalam pengumpulan data untuk penelitian ini, sebagai berikut:

a. Wawancara

Wawancara adalah pengumpulan data yang dilakukan dengan bertanya jawab langsung kepada responden. ${ }^{15}$ Data yang didapat dalam wawancara ini adalah semua data yang digunakan untuk proses penelitian mulai dari aktivitas kegiatan, informasi tentang bahan baku, biaya over head pabrik yang mempengaruhi perhitungan harga pokok produksi dengan sistem job order costing

Wawancara dalam penelitian ini adalah wawancara untuk mendapatkan data mengenai prosedur produksi produk Maju Jaya Aluminium secara umum, selain itu wawancara juga difokuskan pada biaya- biaya apa saja yang dilakukan dalam proses produksi hingga output yang dihasilkan beserta dengan besarnya biaya.

b. Observasi

Observasi merupakan serangkaian aktivitas yang dilakukan oleh peneliti terhadap suatu proses atau objek dengan maksud untuk memahami pengetahuan dari sebuah fenomena atau perilaku berdasarkan pengetahuan dan gagasan yang sudah diketahui sebelumnya. Observasi bisa diartikan sebagai suatu pengamatan yang dilakukan terhadap objek penelitian. ${ }^{16}$ Jadi, observasi yang dilakukan penulis dengan bentuk pengamatan terhadap jalannya produksi, dan beberapa hal yang tekait dengan kebutuhan dari penelitian ini.

c. Dokumentasi

Setiap penelitian yang dilakukan perlu pendokumentasian sebagai bukti telah

\footnotetext{
${ }^{14}$ Eko Putro Widoyoko, Teknik Penyusunan Instrumen Penelitian, ( Cet.1; Yogyakarta: Pustaka Belajar, 2012), h. 53.

${ }^{15}$ Hendri Tanjung dan Abrista Devi, Metodologi Penelitian Ekonomi Islam, Ed. 1 ( Cet. I; Jakarta: Gramata Publishing, 2013), h. 83.

${ }^{16}$ Hendri Tanjung dan Abrista Devi, Metodologi Penelitian Ekonomi Islam..., h. 93

Jurnal Ilmiah Al Tsarwah 150 
dilakukan penelitian dan sebagai pencatatan. Menurut Deddy Mulyana, suatu dokumen dapat mengungkapkan bagaimana subjek mendefinisikan dirinya sendiri, lingkungan, dan situasi yang dihadapinya pada suatu saat, serta bagaimana kaitan antara definisi diri tersebut dalam hubungan dengan orang-orang di sekelilingnya dengan tindakan-tindakannya. ${ }^{17}$

Dalam penelitian ini metode dokumentasi digunakan untuk mengumpulkan data tentang biaya- biaya yang telah dikeluarkan usaha terkait untuk penetuan harga pokok produksi dan juga daftar penjualan produk pada Maju Jaya Aluminium.

d. Teknik Analisis Data

Dalam menganalisis data, penulis menggunakan teknik analisis data metode deskriptif kualitatif. Metode ini digunakan untuk menganalisis perhitungan harga pokok produksi yang dilakukan oleh Maju Jaya Aluminium selama ini. Setelah itu, menganalisis penerepan metode job order costing untuk menghitung harga pokok produksi pada produk Maju Jaya Aluminium, dan juga, dengan penetapan harga jual yang tepat. Membahas dan menerangkan hasil penelitian dengan mempertimbangkan dan membandingkan antara penyusunan harga pokok produksi dari keduanya. Berikut tahapan dalam penelitian ini sebagai berikut:

1) Analisis harga pokok produksi dengan menggunakan metode perusahaan

Analisis dilakukan terhadap 1 produk aluminium pada Maju Jaya Aluminium yang banyak di pesan konsumen selama bulan Mei 2018.

2) Pengumpulan dan pengelompokan biaya

Biaya- biaya yang terjadi selama bulan Mei 2018 dikumpulkan dan dikelompokkan berdasarkan biaya produksi dan biaya non produksi. Selanjutnya dianalisis mana yang merupakan komponen biaya produksi sehingga dapat dilakukan perhitungan harga pokok produksi dengan cepat.

3) Analisis harga pokok produksi dengan metode Job order costing

Job order costing diawali dengan identifikasi proses produksi yang dilakukan oleh

\footnotetext{
${ }^{17}$ Deddy Mulyana, Metodologi Penelitian Kualitatif: Paradigma Baru Ilmu Komunikasi dan Ilmu Sosial Lainnya, (Cet. III ; Bandung : Remaja Rosdakarya, 2004), h. 195
} 
usaha terkait dan biaya- biaya yang digunakan untuk memproduksi produk. Biaya tersebut meliputi biaya bahan baku, biaya tenaga kerja langsung, dan biaya over head pabrik. Berikut perhitungan harga pokok produksi dengan metode Job order costing:

\section{HASIL DAN PEMBAHASAN}

Perbandingan Perhitungan Harga Pokok Produksi Yang Selama Ini Dilakukan Oleh Maju Jaya Aluminium Dengan Metode Perhitungan Harga Pokok Produksi Menggunakan Job Order Costing

Hasil perbandingan kedua metode yang selama ini digunakan oleh Maju Jaya Aluminium dengan perhitungan menggunakan Metode Job Order Costing berikut terdapat pada Tabel 1:

Tabel 1

Perbandingan Perhitungan Harga Pokok Produksi oleh Maju Jaya Aluminium dengan Menggunakan Metode Job Order Costing

\begin{tabular}{|c|c|c|c|}
\hline \multirow[b]{2}{*}{ Unsur Biaya } & \multicolumn{2}{|r|}{ Metode } & \multirow[b]{2}{*}{$\begin{array}{l}\text { Selisi } \\
\text { h (Rp) }\end{array}$} \\
\hline & $\begin{array}{c}\text { Maju } \\
\text { Jaya } \\
\begin{array}{c}\text { Aluminium } \\
(\mathrm{Rp})\end{array} \\
\end{array}$ & $\begin{array}{c}\text { Job Order } \\
\text { Costing (Rp) }\end{array}$ & \\
\hline \multirow[t]{6}{*}{ Biaya Bahan Baku } & 1.200 & & 111.00 \\
\hline & .000 & & 0 \\
\hline & & & \\
\hline & & & \\
\hline & & & \\
\hline & & & \\
\hline
\end{tabular}

Jurnal Ilmiah Al Tsarwah 


\begin{tabular}{|c|c|c|c|}
\hline Biaya Tenaga Kerja & 50.00 & 50.00 & - \\
\hline Langsung & 0 & 0 & \\
\hline $\begin{array}{l}\text { Biaya Overhead } \\
\text { Pabrik: }\end{array}$ & & & \\
\hline $\begin{array}{l}\text { Biaya bahan } \\
\text { penolong }\end{array}$ & & $\begin{array}{r}74.50 \\
0\end{array}$ & - \\
\hline Biaya listrik & & $\begin{array}{r}17.54 \\
7\end{array}$ & - \\
\hline Biaya telepon & & 3.656 & - \\
\hline $\begin{array}{l}\text { Biaya Sewa } \\
\text { gedung }\end{array}$ & & $\begin{array}{r}20.00 \\
0\end{array}$ & - \\
\hline $\begin{array}{c}\text { Biaya perawatan } \\
\text { dan pemeliharaan mesin }\end{array}$ & & $\begin{array}{r}33.63 \\
2\end{array}$ & - \\
\hline $\begin{array}{l}\text { Biaya penyusutan } \\
\text { mesin dan peralatan }\end{array}$ & & $\begin{array}{r}40.88 \\
2\end{array}$ & - \\
\hline HPP Per Bulan & 15.600 .000 & $\begin{array}{l}15.95 \\
0.604 \\
\end{array}$ & $\begin{array}{r}350.60 \\
4 \\
\end{array}$ \\
\hline HPP Per Produk & $\begin{array}{r}1.300 \\
.000\end{array}$ & $\begin{array}{r}1.329 \\
.217\end{array}$ & 29.217 \\
\hline $\begin{array}{r}\text { Tingkat } \\
\text { Keuntungan }\end{array}$ & $\begin{array}{r}19,6 \\
\%\end{array}$ & $\begin{array}{r}19,6 \\
\%\end{array}$ & - \\
\hline Harga Jual & 1.550 & 1.589 & 39.744 \\
\hline
\end{tabular}




\begin{tabular}{|l|l|l|l|}
\hline & .000 & .744 & \\
\hline
\end{tabular}

Sumber : Data primer diolah, Mei 2018

\section{Keterangan :}

Dari penelitian yang dilakukan pada Maju Jaya Aluminium ditemukan perbedaan antara harga pokok produksi yang ditentukan usaha tersebut, dengan harga pokok produksi dengan metode Jon Order Costing. Perbedaan tersebut antara lain adalah:

1. Biaya bahan baku

Perhitungan Maju Jaya Aluminium lebih tinggi karena memasukkan biaya bahan baku penolong ke dalam perhitungan bahan baku yang seharusnya dipisahkan dan biaya bahan baku kaca yang diperhitungkan tempat usaha tidak sesuai dengan biaya pemakaian dan juga Maju Jaya Aluminium tidak membebankan biaya angkut pembelian bahan baku. Selain itu yang menyebabkan nilai biaya bahan baku yang ditetapkan perusahaan lebih tinggi dibanding dengan menggunakan metode Job Oerder Costing karena pada perhitungan pemilik usaha menghitung semua biaya bahan baku kaca sebanyak 3,5 lembar dengan harga $R p 605.500$ padahal yang digunakan untuk pembuatan etalase hanya lah sekitar 3 lembar dengan harga $\mathrm{Rp}$ 519.000. sehingga terdapat selisih dari penggunaan kedua metode yang digunakan.

2. Biaya Tenaga Kerja Langsung

Perhitungan biaya tenaga kerja langsung yang digunakan Maju Jaya Aluminium dengan menggunakan Metode Job Order Costing tidak terdapat perbedaan yaitu membebankan apbiaya tenaga kerja langsung $\mathrm{Rp} 50.000$ setiap produksi atau satu etalase yang dihitung berdasarkan pengerjaan dari dua tahap yaitu pemotongan dan perakitan dengan biaya $\mathrm{Rp} 8.333$ per tahap dan dibebankan apabila sudah mencapai 3 hari atau selesainya pembuatan etalase tersebut . 
sehingga jika diakumulasikan biaya tenaga kerja langsung untuk satu produk etalase dalam jangka waktu 3 hari adalah Rp 50.000 dan sesuai dengan teori akuntansi biaya.

3. Biaya Overhead pabrik

Maju Jaya Aluminium menghitung biaya overhead pabrik ke dalam biaya lainlain, yang dihitung adalah segala biaya yang dikeluarkan Maju Jaya Aluminium selain biaya tenaga kerja dan biaya bahan baku, biaya transportasi dan banak lagi biaya yang seharusnya dimasukkan dalam perhitunga biaya overhead tapi tidak dimasukkan. Sedangkan biaya overhead yang ditentukan dengan metode Job Order Costing adalah biaya produksi selain biaya bahan baku, dan biaya tenaga kerja langsung, yang terdiri dari biaya tidak langsung, biaya penyusutan, biaya bahan penolong, biaya sewa gedung, listrik, telepon, dan biaya perawatan mesin dan peralatan. Dari metode Perhitungan yang dilakukan Maju Jaya Aluminium dinilai kurang tepat karena belum mengenal istilah biaya Overhead pabrik, sedangkan pada perhitungan metode Job Order Costing mengidentifikasi secara terpisah komponen biaya overhead pabrik.

4. Harga Pokok Produksi

Terdapat selisih yang cukup besar antara perhitungan ke dua metode harga pokok produksi selama bulan Juni yaitu sebesar Rp 350.694 dan selisih harga pokok produksi per produk etalase sebesar Rp 29.217. dengan metode Job Order Costing harga pokok produksi sebulan adalah $\mathrm{Rp} 15.950 .604$ dan harga pokok produksi per etalase sebesar Rp 1.329.217, sedangkan dengan metode yang digunakan pemilik usaha Maju Jaya Aluminium lebih rendah selama satu bulan yaitu $\mathrm{Rp} 15.600 .000$ dan harga pokok produksi permeternya sebesar Rp 1.550 .000

Jurnal Ilmiah Al Tsarwah 


\section{Penetapan Harga Jual}

Dari tingkat keuntungan yang ditetapkan Maju Jaya Aluminium yaitu 19,6\% dengan harga pokok produksi atau total biaya sebesar Rp 1.300.000 dengan penetapan harga jual sebesar Rp 1.550.000 dengan keuntungan sebesar Rp 250.000. dari perhitungan biaya atau harga pokok produksi dengan metode Job Order Costing menggunakan tingkat keuntungan atau pencapai laba yang diinginkan yaitu $19,6 \%$ dengan harga pokok produksi atau total biaya senilai 1.329.217 sehingga ditetapkan harga jual senilai $\mathrm{Rp} 1.589 .744$ dengan perolehan keuntungan senilai $\mathrm{Rp} 260.527$. jadi selisih harga jual dengan tingkat keuntungan atau laba 19,6\% antara metode Maju Jaya Aluminium dengan Metode Job Order Costing adalah senilai Rp 39.744.

\section{Aspek maslahah terhadap penerapan Metode Job Order Costing dalam menghitung harga pokok produksi etalase jenis 2 M CA.}

Maslahah adalah segala bentuk keadaan baik material maupun non material yang mampu meningkatkan kedudukan manusia sebagai makhluk yang paling mulia. Kandungan maslahah terdiri dari manfaat dan berkah. Pemilik maju Jaya Aluminium selaku produsen, dalam menghitung biaya yang digunakan selama proses produksi untuk menetapkan harga jual, tentu akan mempertimbangkan manfaat dan berkah yang dihasilkan dari proses perhitungannya agar tetap tertanam nilai keadilan antara pada diri produsen maupun pada konsumen atau pemesan.

Maju Jaya Aluminium akan merasakan manfaat karena mendapatkan keuntungan yang wajar dan sesuai dengan biaya yang seharusnya dibebankan. Dengan menggunakan metode job order costing dilengkapi dengan kartu biaya atau harga pokok yang merinci semua biaya yang digunakan dengan detail, sehingga tidak ada lagi biaya yang seharusnya dibebankan pada perhitungan harga pokok produksi maupun harga jual tetapi tidak dibebankan, begitupun sebaliknya.

Jurnal Ilmiah Al Tsarwah 
Berkah akan diperoleh Maju Jaya Aluminium selaku produsen dalam menghitung biaya atau harga pokok produksi dengan metode job order costing apabila pemilik Maju Jaya Aluminium menghitungnya dengan cara adil,terbuka dan transfaransi. Menerapkan nilai keadilan dan meniatkan pekerjaan tersebut tdak lain hanya untuk mendapat ridho Allah SWT.

\section{KESIMPULAN DAN SARAN}

Kesimpulan

Dari hasil penelitian dan evaluasi yang telah dilakukan terhadap Maju Jaya Aluminium mengenai peran Job Order Costing dalam menentukan harga pokok produksi, maka dapat diambil beberapa kesimpulan sebagai berikut:

1. Maju Jaya Aluminium menerapkan perhitungan harga pokok produksi masih sangat sederhana yaitu dengan menjumlahkan biaya bahan baku, biaya tenaga kerja, dan biaya lain-lain, biaya lain- lain merupakan biaya produksi yang dikeluarkan Maju Jaya Aluminium di luar biaya bahan baku dan biaya tenaga kerja, karena usaha tersebut belum mengenal biaya overhead. Perhitungan harga pokok produksi etalase jenis $2 \mathrm{M} \mathrm{CA}$ dengan tingkat keuntungan yang ditetapkan Maju Jaya Aluminium 19,6\% dengan harga jual per etalase 1.550 .000 adalah dengan harga pokok produksi Rp 1.300.000.

2. Berdasarkan perhitungan dengan metode Job Order Costing harga pokok produksi pesanan etalase jenis 2M CA adalah sebesar Rp 1.329.217 dengan tingkat keuntungan yang ditetapkan 19,6\% sehingga penetapan harga jual etalasejenis 2M CA senilai Rp 1.589.744 .dengan tingkat keuntungan 19,6\% . Dengan metode Job Order Costing, menjumlahkan biaya bahan baku dengan membebankan biaya angkut bahan baku, biaya tenaga kerja, dan biaya

Jurnal Ilmiah Al Tsarwah

Program Magister Program Studi Ekonomi Syariah

Institut Agama Islam Negeri (IAIN) Bone 
overhead pabrik yang terdiri dari biaya bahan penolong, biaya listrik dan telepon, biaya sewa gedung, biaya pemeliharaan mesin dan peralatan serta penyusutan mesin dan peralatan.

3. Berdasarkan perhitungan harga pokok produksi antara metode Maju Jaya Aluminium dengan Metode Job Order Costing diperoleh selisih sebesar Rp 29.217. yang diperoleh dari $\mathrm{Rp} 1.300 .000$ harga pokok produksi menurut metode Maju Jaya Aluminium dan Rp 1.329.217 menurut metode Job Order Costing. Berdasarkan tingkat kauntungan yang ditetapkan usaha terkait, senilai 19,6\% sehingga harga jual yang diperoleh dari kedua metode tersebut dari harga pokok produksi diperoleh sebesar Rp 1.550.000 menurut metode Maju Jaya Aluminium dan $\mathrm{Rp}$ 1.589.744 menurut hasil perhitungan harga pokok produksi dengan metode Job Order Costing.

Perbedaan utama antara ke dua metode tersebut terletak pada biaya bahan baku dan biaya overhead pabrik. Perbedaan nilai yang dihasilkan disebabkan metode yang digunakan oleh perusahaan dalam menghitung biaya bahan baku memasukkan biaya bahan baku penolong ke dalamnya yang seharusnya dipisahkan dan biaya bahan baku kaca yang diperhitungkan tempat usaha tidak sesuai dengan biaya pemakaian dan juga Maju Jaya Aluminium tidak membebankan biaya angkut pembelian bahan baku. Selain itu tidak membebankan biaya overhead pabrik secara tepat, karena perusahaan hanya mengira- ngira dengan memasukkannya ke dalam biaya lain-lain senilai 50.000. perusahaan tidak mengetahu unsur harga pokok produksi sesuai kaidah akuntansi biaya secara benar, sehingga harga pokok produksi yang dihitung oleh perusahaan dalam menentukan harga jual pada suatu pesanan menjadi terlalu tinggi atau rendah. Perhitungan harga pokok produksi menjadi salah satu hal penting untuk dilakukan bagi setiap usaha atau perusahaan dalam menetapan harga jual.

\section{Saran}

Jurnal Ilmiah Al Tsarwah

Program Magister Program Studi Ekonomi Syariah

Institut Agama Islam Negeri (IAIN) Bone 
Berdasarkan bukti dari hasil penelitian yang telah dilakukan dengan perbandingan antara perhitungan Maju Jaya Aluminium dengan metode Job Order Costing dapat memberikan saran sebagai berikut:

1. Setiap pesanan hendaknya pihak Maju Jaya Aluminium melakukan identifikasi biaya produksi terlebih dahulu, agar harga pokok produksi yang ditentukan tepat. Hal ini dilakukan karena tiap pesanan memiliki spesifikasi yang berbeda sehingga biaya produksinya pun berbeda.

2. Perbedaan yang terjadi dalam perhitungan harga pokok produksi menurut Maju Jaya Aluminium dengan metode Job Oreder Costing harus menjadi perhatian khusus dari manajemen dalam menentukan harga pokok produksi dan penentuan tingkat keuntungan atau harga jual yang diharapkan perusahaan. Tindakan yang harus diambil adalah dengan melakukan koreksi perhitungan harga pokok produksi sesuai dengan metode Job Order Costing dengan menghitung dan mengidentifikasi biaya bahan baku, biaya tenaga kerja langsung, dan biaya ovrhead pabrik.

3. Dengan menerapkan metode Job Order Costing dengan benar dalam menghitung harga pokok produksi untuk penetapan harga jual, seharusnya Bapak A. Yusran juga menerapkan prinsip- prinsip keislaman dalam kegiatan produksi maupun caranya dalam menetapakan semua biaya dalam hal ini prinsip adil, transparan, saling menguntungkan dan yang terpenting memperbaiki niat dalam setiap memulai kegiatan produksi maupun dalam mengakumulasi biaya yang sesuai pemakaian. Agar tercipta rasa suka sama suka dari hasil yang diharapkan antara pemilik dengan konsumen. Sehingga akan tercapai kemaslahatan bagi ke dua belah pihak.

\section{DAFTAR PUSTAKA}

Amanda Metallita, Dewi. "Analisis Perhitungan Harga Pokok Produksi Industri Usaha Kecil dan Menengah Produk Percetakan pada CV. Miranti , Bogor". Skripsi, Program Sarjana AlihJenis Manajemen Institut Pertanian Bogor,2013. 
Anggipora,Marius P. Dasar- Dasar Pemasaran. Cet. 1; Raja Grafindo Persada: Jakarta, 1999.

Anorga, Wie'ns Kamus istilah ekonomi : Inggris- Indonesia, Indonesia- Inggris.Bandung: CV. M2S Bandung, 2009.

Anton, " Analisis penetuan harga pokok produksi menggunakan metode activited based costing ( studi kasus pada PT Bintang Semarang) ", Vol. 3, No 3, September, 2012.

Arbianto, "Analisis penerapan Sistem Activity Based Costing ( Abc) untuk memperoleh suatu harga pokok produksi yang lebih akurat dan digunakan sebagai alat pengendalian terhadap biaya". Skripsi, Universitas Negeri Sultan Syarif Kasim Riau, Pekanbaru, 2011.hal. 2.

Bastian, dkk, Akuntansi Biaya Ed. 4. Jakarta: Mitra Wacana Media, 2013.

Bungin, Burhan. Sosiologi Komunikasi : Teori, Paradigma, dan Diskursus Teknologi Komunikasi di Masyarakat Ed. 1. Cet. VI; Jakarta: Kencana Prenada Group, 2013.

Call S, Warren. Prinsip- Prinsip Akuntansi. Cet. I; Jakarta:Erlangga, 2000.

Chamid, Nur .Jejak Langkah Sejarah Pemikiran Ekonomin Islam.Cet. I; Yogyakarta: Pustaka Pelajar, 2010.

Departemen Agama RI, Ummul Mukminin : Al-Qur'an dan terjemahan,..,h.391.

Departemen AgamaRI ,Ummul Mukminin : Al-Qur'an dan Terjemahnyauntuk Wanita .Jakarta Selatan: WALI : Oasis Terrace Recident, 2016,

Departemen Pendidikan Nasional, “ Kamus Besar Bahasa Indonesia”. Cet. III; Jakarta: Balai Pustaka, 2005.

Enita. Metode Harga Pokok Pesanan ( Job Order Costing Method)" dalam https://www.kompasiana.com, 9 November 2015

Ensiklopedia ekonomi, Bisnis dan Manajemen. Cet. II; PT Delta Pemungkas: Jakarta, 1997.

Farkhan Tsani, Ali . Mi'raj islamic news agency, bekerja ikhlas karena Allah, jumat, 29 july 2016 06; 26 WIB

Febriani,Alvera Kurnia. "Penggunaan Metode Job Order Costing Sebagai Penentu Cost Of Goodanufactured ( Studi Kasus pada Youdesign Digital Printing Semarang", Skripsi, Universitas Dian Nuswantoro Semarang, Semarang. 2014.

Ghofur, Abdul .Pengantar Ekonomi Syariah: Konsep Dasar, Paradigma, Pengembangan Ekonomi Syariah.Cet.1; Jakarta : Rajawali,2017.

Jurnal Ilmiah Al Tsarwah 
Ghofur, Abdul Pengantar Ekonomi Syariah: Konsep Dasar, Paradigma, Pengembangan Ekonomi Syariah .Cet.1; Jakarta : Rajawali,2017.

Hansen and Women, Akuntanasi Manajerial Ed. 8. Salemba Empat: Jakarta, 2011.

Hasan, Iqbal. Analisis Data Penelitian dengan Statistik . Cet.4; Jakarta:Bumi Aksara,.

Hery. Cara Mudah Memahami Manajemen Biaya. Cet. 1;Yogyakarta:Gava Media.

Horngren, Charles T. Cost Accounting : A Managerial Amphasis, Thirteenth Edition. Person Education, Inc, 2009.

llyas,Baharuddindan Muhammad Arif Tiro, Metodologi Penelitian untuk IImu-IImu sosial dan Ekonomi. Cet. I; Makassar: Andira Publisher, 2002.

Islaili, Nurul. "Harga Pokok Produksi Untuk Menentukan Harga Jual PadaUKM Caula Di Sidoarjo" Sekolah Tinggi IImu Ekonomi Indonesia (STIESIA) Surabaya, Vol. 2, NO. 8, 2013.

K. Carter ,William dan Milton F. Usry, Akuntansi Biaya. Jakarta: Salemba Empat, 2004.

Karim, Adiwarman .Ekonomi Mikro Islam.Cet.3;Jakarta: Raja Grafindo Persada,2008.

Kurnia Febriani, Alvera. "Penggunaan Metode Job Order Costing Sebagai PenentuCost Of Goods Manufactured (Studi Kasus Pada Youdesign Digital Printing Semarang)", Tinjauan terhadap Buku Penganggaran Perusahaan , oleh Darsono dan Purwanti,2014.

Machfoedz. Pengantar Pemasaran Modern. UPP AMP YKPN: Yogyakarta, 2005.

Maulana , Rizal ." Perhitungan Harga Pokok Produksi Dengan Job Order CostingMethod Guna Meningkatkan Akurasi Laba Pada PerusahaanMebel Ud. Cipta Jaya Demak" , Tinjauan terhadap Buku Akuntansi Biaya, oleh Mursyidi,2015.

Mulyadi Soepardi, Eddy. Memahami Akuntansi Keuangan. Jakarta: PT Raja Grafindo Persada, 2006.

Mulyadi, Akuntansi Biaya, Ed. 5. Cet. 2; AMP YKPN YOGYA: Yogyakarta, 2009.

Mulyadi,_Akuntansi Biaya Ed. 5. Cet. 10; Yogyakarta: Unit Penerbit dan Percetakan Sêkolah Tinggi Ilmu Manajemen YKPN, 2010.

Mulyana,Deddy.Metodologi Penelitian Kualitatif: Paradigma Baru IImu Komunikasi dan IImu Sosial Lainnya.Cet. III ; Bandung : Remaja Rosdakarya, 2004.

Nata, Abuddin .Metodologi Study Islam, Ed.I. Cet. VII; Jakarta: PT. Raja Grafindo Persada, 2003

Jurnal Ilmiah Al Tsarwah 
Prima Dewi, Sofia dan Septian Bayu Kristianto. Akuntansi Biaya, Ed. 2. IN MEDIA: Bogor, 2014.

Purnama, Panji. " Penggunaan Job Order Costing Method Dalam MenentukanHarga Pokok Produksi Untuk Meningkatkan AkurasiHarga Jual ProdukPada Percetakan Cv. Pustaka Indah Semarang", Tinjauan terhadap buku Akuntansi Biaya, oleh Willian K. Carter, 2014. 